\title{
Critical Success Factors for the Adoption of Decision Tools in IPM
}

\author{
Vittorio Rossi ${ }^{1}$, Giorgio Sperandio ${ }^{2,3}$ (), Tito Caffi ${ }^{1}$, Anna Simonetto ${ }^{2,3}$ () and Gianni Gilioli ${ }^{2, *}$ \\ 1 Department of Sustainable Crop Production, Università Cattolica del Sacro Cuore, Via Emilia Parmense, 84, \\ 29122 Piacenza, Italy; vittorio.rossi@unicatt.it (V.R.); tito.caffi@unicatt.it (T.C.) \\ 2 Department of Molecular and Translational Medicine, Università di Brescia, Viale Europa, 11, 25123 Brescia, \\ Italy; giorgio.sperandio@unibs.it (G.S.); anna.simonetto@unibs.it (A.S.) \\ 3 Department of Life Sciences, University of Modena and Reggio Emilia, Via G. Campi, 213/d, 41125 Modena, Italy \\ * Correspondence: gianni.gilioli@unibs.it; Tel.: +39-030-371-7712
}

Received: 31 August 2019; Accepted: 1 November 2019; Published: 3 November 2019

check for updates

\begin{abstract}
The rational control of harmful organisms for plants (pests) forms the basis of the integrated pest management (IPM), and is fundamental for ensuring agricultural productivity while maintaining economic and environmental sustainability. The high level of complexity of the decision processes linked to IPM requires careful evaluations, both economic and environmental, considering benefits and costs associated with a management action. Plant protection models and other decision tools (DTs) have assumed a key role in supporting decision-making process in pest management. The advantages of using DTs in IPM are linked to their capacity to process and analyze complex information and to provide outputs supporting the decision-making process. Nowadays, several DTs have been developed, tackling different issues, and have been applied in different climatic conditions and agricultural contexts. However, their use in crop management is restricted to only certain areas and/or to a limited group of users. In this paper, we review the current state-of-the-art related to DTs for IPM, investigate the main modelling approaches used, and the different fields of application. We also identify key drivers influencing their adoption and provide a set of critical success factors to guide the development and facilitate the adoption of DTs in crop protection.
\end{abstract}

Keywords: decision tools; integrated pest management; decision support systems; pest management; crop protection

\section{Integrated Pest Management: Principles, Barriers and Benefits}

Integrated pest management (IPM) aims at protecting crops against pests (i.e., any species, strain, or biotype of plant, animal, or pathogen injurious to plants or plant products [1]) keeping pesticides and other interventions to levels that are economically and ecologically justified, thus reducing or minimizing the risks for humans and the environment [2,3]. This concept was used for the first time by Smith and van den Bosch in 1967 [4] and nowadays, several policies and extension strategies linked to crop protection are inspired by IPM principles all over the world [5-7]. IPM relies on an integrated evaluation of the dynamic processes characterising the agricultural ecosystems and their components (e.g., plants, animals, environment, human intervention) towards a long-term sustainability of crop production and pest control [3,8,9]. Ensuring the routine monitoring of pests, the use of action thresholds (i.e., the minimum pest population abundance that justifies the application of a treatment [10]), and the rational and sustainable use of pesticides [11] are the pillars of IPM. According to Barzman and colleagues [3], IPM is based on eight principles: (1) Prevention of pest occurrence and suppression of pest populations; (2) monitoring of harmful pests; (3) informed decision-making; 
(4) priority to non-chemical methods; (5) multi-criteria selection of pesticides; (6) pesticide use reduction; (7) avoidance of pests resistance to pesticides; and (8) evaluation.

The application of IPM concepts and practices might lead to an increased profit for farmers while ensuring the successful management of pests [12-16]. Beyond successful control of pests, IPM might increase the overall farm resilience and contribute to increasing the natural capital and to preserve and/or foster the provision of ecosystem services [17]. Despite the potential benefits, IPM did not have the success expected and its application is still partial and jeopardized [18-20]. Farmers perceive IPM as complex, time- and labour-consuming, difficult to implement, and linked to lower or to unpredictable economic advantages with respect to conventional or organic farming $[2,16,20,21]$. Indeed, IPM may be knowledge-intensive and requires time and resources for planning activities, and integrating various sources of information for informed decision-making under uncertain conditions [22-25]. Complexity of decision-making is another important limiting factor preventing a wider implementation of IPM worldwide. The decision making in IPM concerns the complexity of the processes relating to the three levels involved (strategic, tactical, and operational) [26,27] (Figure 1). At the strategic level, the overall approach implemented against pests and the long-term decision-making at both the farm level (e.g., crop rotation) and at the field level (e.g., the plant variety to be grown) need to be defined. At the tactical level, the different methodologies that can be used to implement a strategy are considered, and it requires day-by-day decision-making in response to the crop overall status (e.g., treatment against a disease outbreak). At the operational level, fast responses with respect to the crop or within the crop conditions (e.g., treatment to be adapted to the size of the canopy) or unpredictable events (e.g., rainfall that delays the treatment of a pest) are selected and implemented.

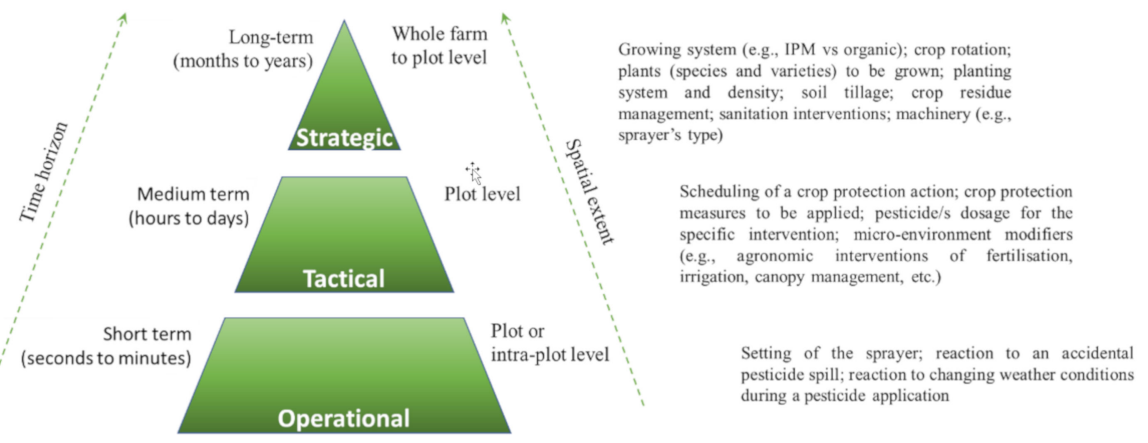

Figure 1. Relationship between the decision-making process and the type of operation in integrated pest management (IPM) at various spatio-temporal scales.

Adequate pest monitoring, using suitable methods and tools, including field observations, use of insect/spore traps, and forecasting systems, are essential for guiding decision-making in IPM. From the end-users' perspective, access to up-to-date information related to crops and pests, and to the available scientific and technical innovations, is required. Furthermore, decision-making in IPM should consider the specific local conditions related to environmental variables, land-use schemes, farmers' socio-economic conditions, and other relevant information in order to make IPM programmes flexible and adaptable to the specific needs $[18,28]$. To support decision-making (at strategic, tactical, and operational levels) in crop protection, a large number of tools predicting the dynamics of organisms harmful to crops and guiding their management have been developed, including population dynamics and epidemiological models, risk algorithms, intervention thresholds, decision rules, and decision support systems (DSSs). All these tools are collectively named decision tools (DTs) in this review. The overall scope of DTs for IPM is to support knowledge-based management of harmful organisms in agriculture. DTs help decision-makers in solving complex problems while reducing the time and the resources allocated for analyzing the available information and selecting the best solution [29].

Here, we provide a short review of the current knowledge and state-of-the-art related to the types of DTs supporting strategic, tactical, and operational decision-making for the management of crop 
pests. The aim is to investigate and define the combination of important factors required in order to reach the goal of effective DTs implementation, i.e., the so-called 'critical success factors' in IPM programs [30].

\section{Decision Tools for IPM}

Since 1980, an increasing number of DTs were developed for supporting farmers, practitioners, and farm managers in their decision-making at various spatio-temporal scales [31,32]. Thanks to the increasing availability of personal computers and modems at farm level, many government-funded programs were created worldwide with the aim to boost the introduction of these new technologies, enhancing the use of computers on farms, the development of pest and disease models, and the exchange of information [33]. In the European Union (EU), for example, some concerted actions (e.g., the European network for operational and tactical DSS on crop protection (EU.NET.DSS) and European cooperation in science and technology (EU-COST) actions were specifically supported for encouraging both the development and introduction of this new information technology as a common initiative). The epidemic prevention (EPIPRE) system for supervised integrated control of wheat diseases [34] represented one of the earliest experience of a computer-based advisory systems in Europe. These DTs have been developed and/or adapted by: (i) Public research and extension services; (ii) plant protection organizations; (iii) private companies/groups marketing products or services or providing consultancy to farmers. The number of DTs available for crop protection rapidly increased worldwide. In Europe, for example, the EU-funded project ENDURE reviewed 70 systems implemented in the EU in 2008 [35] while this number increased up to more than 200 in 2018, covering 32 crops, as result of the inventory performed by the SHARE4IPM (Table A1). DTs currently applied in pest management vary in terms of structure, complexity, and type of output provided. The most advanced DTs used in IPM programs are represented by the DSSs as they comprise an interconnected technological infrastructure including: (i) Sensors and tools for data collection; (ii) databases for data storage and management; (iii) tools for data analysis; (iv) automatic procedures for data interpretation; and (v) a user-friendly interface [27,36]. Currently, the access to DTs by users (e.g., farmers, agricultural advisers, policymakers) is uneven and restricted to particular areas and/or groups of users because of the diversity of the systems and the crops to be managed. However, DTs might be potentially used at a wider scale and applied to different agro-climatic conditions.

\subsection{Benefits of Decision Tools in IPM}

The main advantage of using DTs is linked to their capacity of processing, analyzing, and summarising relevant input data, making them available to the end-users in a suitable form (e.g., graphs, tables, etc.) for decision-support purposes [25,37]. DTs used in pest management provide several types of information as, for instance, predictions of the timing of pest potential emergence, pest abundance, and impacts as influenced by biotic and abiotic driving variables and the effects of management practices [25]. The main outputs of DTs are accessible to the end-user throughout a web-based user-friendly interface or by other means of communication (e.g., phone SMS, e-mails, newsletters, etc.) and targeted to their specific needs [27,32,38]. DTs can be fine-tuned for providing information that falls within the IPM framework (e.g., by providing text advices or suggesting best practices) and supporting the users in implementing the best strategies, tactics, and operations based on the available information [27]. Therefore, DTs represent a valuable contribution for the implementation of IPM at the field level as well as for supporting the implementation of large-scale crop protection policies.

\subsection{Modelling Approaches Used in DTs}

Mathematical and/or statistical models for pest population dynamics and disease epidemiology represent the basis of the vast majority of DTs applied in IPM and broadly, in agriculture [27]. A model can be defined as a simplified representation of a part of reality (e.g., an object, a process, etc.) based on 
the current available knowledge [39]. Empiric and mechanistic models are the most relevant categories of models in supporting decision-making in IPM:

- Empiric (data-based) models organizing data and standardising their relationship in terms of mathematical or statistical representations (e.g., correlation between pest abundance and air temperature). Empiric models provide useful insight to explore the relationships within a system that are unknown or poorly known;

- Mechanistic or process-based models describing a process (e.g., pest population dynamics/epidemics) based on the underlying functional mechanisms of the process. Mechanistic models are crucial to evaluate the biological responses as function of one or more environmental independent variables (e.g., air temperature, relative humidity, etc.).

The decision about the type of modelling approach to implement is fundamental when developing a DT. Data-based models were the most frequently used in the past. The first approaches based on empiric models were limited in providing explicit information on the underlying processes linking pest population distribution, abundance, and impacts with the environmental driving variables. Mechanistic models are highly reliable in investigating how biotic and abiotic drivers influence individual's life-history and, in turn, the overall population dynamics/epidemics. Furthermore, mechanistic models seek the dynamical description of the biological and physiological responses in relation to the population dynamics and epidemics, both in space and time, of the environmental drivers [40]. The bottom-up approach used in mechanistic models requires that the underlying mechanisms of the processes involved (population dynamics/epidemics are previously known in detail [40]. Despite the need for detailed knowledge about the processes involved, the amount of data needed for the development of mechanistic models is usually lower relative to the data required for the development of empiric models that have been proposed more recently in agriculture [27]. Table 1 shows a schematic representation of the main characteristics of data models and mechanistic models.

Table 1. Main characteristics of empiric and mechanistic models.

\begin{tabular}{ccc}
\hline Characteristic & Mechanistic Models & Empiric Models \\
\hline Data requirements & $\begin{array}{c}\text { Data on biological response to } \\
\text { external drivers are needed }\end{array}$ & $\begin{array}{c}\text { Wide and representative field data are } \\
\text { required for developing the model }\end{array}$ \\
\hline $\begin{array}{c}\text { Knowledge on the organism to } \\
\text { be modelled }\end{array}$ & $\begin{array}{c}\text { Detailed knowledge on } \\
\text { biological processes is required }\end{array}$ & $\begin{array}{c}\text { A specific knowledge on the pest is } \\
\text { not needed }\end{array}$ \\
\hline Explanatory ability & $\begin{array}{c}\text { Seek for a mechanistic } \\
\text { exploration of biological } \\
\text { processes }\end{array}$ & $\begin{array}{c}\text { Do not provide an explanation of the } \\
\text { biological mechanisms underlying } \\
\text { a process }\end{array}$ \\
\hline Predictive ability & $\begin{array}{c}\text { Prediction is possible in a wide } \\
\text { range of agricultural contexts }\end{array}$ & $\begin{array}{c}\text { No prediction is possible outside the } \\
\text { range of input data (extrapolation) and } \\
\text { under different agricultural contexts }\end{array}$ \\
\hline
\end{tabular}

However, the distinction between empiric and mechanistic models is becoming increasingly blurred. Several authors highlighted a continuum across empiric and mechanistic models, with mechanistic models including some data-driven components and empiric models containing mechanistic parts [41]. In addition to this, the capacity of empiric models in including causal processes among variables is increasing and, currently, their capacity of integrating the biology of the species to be modelled is approaching that of mechanistic models (e.g., machine learning). Thus, the choice of the modelling approach to be implemented in developing a DT can take advantage of a wide range of possibilities to be adapted in relation to knowledge and data availability, the level of complexity to be represented, and the type of output required.

Other tools that are implemented in IPM refer to optimization models and expert systems [31,40]. Optimization models focus on supporting the optimization of a process respect to some variables 
(e.g., keep crop losses due to pest below a certain threshold) while satisfying the constraints existing on some process components (e.g., economic and environmental sustainability). For example, these types of models are used in supporting economic decisions related to land use changes in a way that a certain field yields the highest rent [40] or for optimizing the management of pests [42]. Expert systems simulates human decision-making to solve complex problems in a very specific domain. They are computer systems reasoning through bodies of knowledge based on a set of defined rules. Expert systems are used, for instance, to support the identification of pests and suggest appropriate treatments [43] or for supporting the development of cropping plans and crop rotation schemes [44].

\subsection{Intended Use of DTs}

The definition of the specific issues to be solved is of paramount importance when developing a DT. This requires a continuous interaction between modellers and users (e.g., farmers, consultants, technicians) in order to develop tools that might resolve specific agricultural or pest management problems. Nowadays, various types of DTs have been developed to respond to various issues related to pest management and crop protection [45]. Some of the most important issues currently addressed by DTs are discussed below. Some of these DTs address strategic decision-making (as in 2.3.1); others support tactic (as in 2.3.2 and 2.3.3) or operational (as in 2.3.4) decisions.

\subsubsection{Decision on Whether Prevention and/or Suppression Measures Are Needed}

The decision on whether to apply measures for prevention and/or suppression is important for the rational management of a pest. Prevention aims at reducing the probability that a pest develops populations that require control interventions by applying agronomic measures that make the environment less conducive for the pest and/or the plant less susceptible to pest attack. These measures include the use of resistant cultivars, the selection of the crop to be grown based on soil characteristics and land use, the regulation of soil drainage, etc. Suppression measures refers to the application of cultural practices (e.g., seed-bed sanitation, management of crop residue, soil tillage, application of chemical treatments) aimed at reducing the pest population during winter or in the inter-crop period, so that the pest development in the following season is delayed [46]. In this regard, DTs are developed to support strategic decisions to develop cropping plans, schedule planting and crop rotation schemes $[47,48]$, assess the risks of crop diseases [43,49], simulate yield loss as a result of pest impacts [50], provide early warnings based on cultivar resistance [44], and support fertilization plans [51-54]. The information provided by DTs might also support the application of suppression measures, for instance, on whether to intervene based on the estimation of the pest population as influenced by environmental (e.g., temperature or rain) and agricultural (e.g., previous crop or soil type) drivers [55-58]. DTs might also be used for interpreting crop protection scenarios, including the potential influence of pests and providing management guidelines to farmers [59].

\subsubsection{Decision on Scheduling Crop Protection Interventions}

In IPM, crop protection interventions might be applied following specific rules (see for example Annex III of the EU Directive 128/2009). Methods for deciding whether and when an intervention is needed include the definition of thresholds for arthropod pests' abundance and the estimation of the level of risk that a crop develops a disease, based on the concept of ecological and economic justification [10]. There are several examples of models developed for supporting the definition of best timing and frequency for the implementation of pest control measures on different crops, in relation to key environmental drivers. For instance, models are available in grapevine for European berry moth [60,61], vine mealybug, and American leafhopper [62], as well as for some diseases like downy mildew [63,64], powdery mildew [65], black rot [66], and botrytis [67]. These DTs allows to predict the insect phenology (e.g., time of emergence) and population dynamics (i.e., pest population abundance) as well as the time of disease outbreak, the infection risk, and the epidemic development. These tools allow the user to identify the optimal timing and frequency for the implementation of pest control 
measures according to the emergence of the stage to be treated and avoiding major impacts on the crop [68]. Similarly, DTs might also support the definition of thresholds to be used in IPM $[69,70]$. To increase model reliability and accuracy, DTs can include details related to pest biology (e.g., voltinism, overwintering strategies, stage of the pathogen), the role of biotic/abiotic drivers such as competition for space, photoperiod, temperature and humidity, seasonality, and host susceptibility [71,72], as well as information on the host plant physiology and phenology [60]. Inclusion of crop responses in the DT supports the assessment of potential impacts (in terms of crop yield and crop quality) due to pests [73-75]. For instance, a model simulating crop losses caused by pests developed through reverse mechanistic modelling [76] may support the implementation of management options and strategies, as well as quantify the gains that could be expected from management. This approach enables addressing individual pathogens/pests in a given crop, as well as combined pests.

\subsubsection{Optimization of Pest Monitoring Programs}

Crop pest monitoring is a pillar of IPM in order to minimize crop losses, optimize pest control, and reduce costs [77]. It mainly involves scouting for pests to determine if, when, and how intervention should occur. Given their costs and time requirements, crop pest monitoring activities must be planned in order to maximize the data gathered per unit of monitoring cost (e.g., visit the crop only when the likelihood of pests to emerge is high). DTs are useful for providing relevant information supporting pests' monitoring programs [78]. Seasonal temperature and rainfall patterns are major factors in ruling pest phenology, emergence, and incidence [79]; DTs supporting pest monitoring must take into account these environmental factors to provide early warnings on the likely onset of a pest or the emergence of the damaging stage of the pest, so that scouting can be organized accordingly $[80,81]$. Biology and ecology of the pest under investigation and the interaction with the physiology and phenology of the host plant are also important factors to be considered in pest monitoring programs and tools [60]. Examples of information provided by these DTs are the time for first occurrence of a certain pest [82], the estimate of immigrant pests from neighboring areas [83], and the onset of plant diseases such as Cercospora leaf spot of sugar beet, or leaf rust of wheat [84].

\subsubsection{Supporting Decision on Pesticide Use}

In IPM, decisions about the use of pesticides should consider both the potential effectiveness of a pesticide to the specific pest to be managed and its specificity for the pest, to minimize the possible effects on non-target organisms, including humans. Chemical inputs shall be kept as low as possible while ensuring efficient pest control and the prevention of the development of resistant pest populations. DTs have been developed to support optimization of pesticide use. These include, among others: (i) Tools for the selection of the pesticides based on multiple and combined factors such as the target organism/s, its/their developmental stage, the pesticide movement on plant surfaces and/or inside the plant tissues, etc. [85]; (ii) pesticide efficacy models [86]; (iii) tools for defining the application rate of pesticides like the tree row volume and leaf wall area calculators [87,88]; and (iv) tools for calibration and setting of sprayers to optimize pesticide distribution on crops [89]. Models simulating the potential effect of plant protection products on pest populations can provide useful insights on pesticide-induced mortality and effectiveness in reducing pest population pressure below a 'safe' threshold [90-92]. Pesticide effectiveness can be assessed under laboratory conditions by exposing the pest to several concentrations of an active substance and/or for different periods of exposure. For insecticides, the effectiveness can be evaluated considering both the instantaneous effects on pest survival or more complex effects involving pest life-history traits (e.g., pesticide effects on development or fertility) [90]. For fungicides, the effectiveness is linked to the physical mode of action (PMoA) of the product. PMoA can be evaluated under environmental controlled conditions with artificial inoculations to investigate the intensity and duration of pre- and post-infection activity, as well as pre- and post-symptom activity, rainfastness, and tenacity of the fungicide under investigation [85]. Recently, a new process-based model, which included functions' parametrization through experimental studies, experts' judgment, 
and technical advice, was elaborated to predict fungicide efficacy dynamics [85]. In order to develop more reliable and realistic DTs, data on pesticide effectiveness must be coupled with other relevant data related to: (i) Pesticide application (e.g., pesticide volume rate, pesticide application frequency); (ii) environmental degradation; (iii) pesticide intake rate; and (iv) chemical degradation/elimination rate in the body organism [93].

\subsubsection{Estimate the Environmental Fate of Pesticides}

Informing decision-makers on pesticide fate can support the optimization of pesticide use in agriculture and also promote a reduction of their use. For this purpose, DTs can provide reliable information on pesticide fate, mobility, persistence, and risks to the environment based on relevant abiotic drivers [94]. To address these aspects, the contribution of environmental components should be considered, including the physical and hydrological characteristics of the soils (e.g., porosity, presence of water), the uptake from vegetation and the environmental drivers (e.g., temperature). For instance, relevant information on the composition of pesticides, their residues, and the formulation of mixtures are provided by the Danish Plantenet system [95]. Moreover, in UK a DT was developed in order to support government stakeholders in the optimization of agricultural pesticide-use policies [96], while in Germany, a DT was developed for assessing the risks to the environment caused by the use of plant protection products [97].

\section{Drivers Influencing the Adoption of DTs for IPM}

Even though many tools supporting decision making have been developed for crop protection, their use in IPM is still jeopardized and restricted to certain areas and/or to a limited group of users [22,98-100]; therefore, the impact of DTs on agricultural practices is still limited [32]. Frequently, the main use of DTs is indirect, via the activities performed by the agricultural advisors that are in charge of running the models in different areas and then distributing model outputs or model-based advices to the final users $[25,101]$. DTs faced, and are still facing $[102,103]$, the so-called 'problem of implementation' that is defined as the 'lack of sustained use in a way that influence practice' [22]. Various authors have analysed the main factors influencing the adoption of DTs in agriculture [23,37,102]. These include their soundness, user-friendliness, ease of use, flexibility, frequency of update, as well as the real and/or perceived benefits envisaged and the previous knowledge of the user [104]. To summarize, under-utilization has been ascribed to two sets of reasons: (i) Technological limitations of decision-support tools and (ii) socio-economic constraints $[23,25]$.

\subsection{Technological Constraints}

Most of the technological constraints identified in the 1990s as potential obstacles to the adoption of DTs in agriculture have been solved by technological progress (i.e., wider access to personal computers, internet and web-based services) [101]. However, despite the widespread advancement and spread of ICT (information and communication technologies) that has occurred in recent years and the increased rate of adoption of these new technologies by farmers [105], some constraints still exist. In the last decade, attention has been directed to investigating the user's perception linked to the role of DTs in the decision-making process [22,102]. In agreement with Matthews and colleagues [102], it is observed that DT developers have focused too much of their attention on implementing advanced technological features, while lower priority was given to ensuring DT's credibility and their capacity to be integrated within the decision-making process.

\subsection{Socio-Economic Constraints}

Socio-economic constraints mostly refer to the real and/or perceived economic advantages that the adoption of a new technology (in our case, a new DT) can bring to the end-user. Kuehne and colleagues [106] developed a quantitative model to define 22 factors influencing adoption of innovations in agriculture, which can be useful for addressing the implementation problem. These factors are 
related to: (i) The ease and speed of learning to use the new tool and (ii) the role of end-users in increasing the perception of the relative advantage of adopting it. Other factors influencing the adoption of innovative DTs were investigated by Rose and colleagues [107] who highlighted the role of easiness to use, cost-effectiveness, efficiency, relevance to the user, and agreement with conformity demands. These factors have been confirmed in other studies [25,102,104,108]. Additional constraints refer to the type of user and its ability and willingness to invest time and efforts in learning and using the DT $[23,109]$.

\section{Towards Wider Adopton of DTs in IPM}

Even though there are factors limiting the adoption of DTs for IPM, examples of their successful application with positive results on crops exist [108,110-112]. Below, we provide a set of critical success factors guiding developers in efficiently conceptualising and implementing DTs, and users selecting DTs to be implemented in practical IPM.

\subsection{The DTs Considers Crop Protection as Part of a Multicomponent System}

DTs often concentrate on a single problem (e.g., a single pest or saving an individual spray), while farmers need to cope with a broad range of multiple issues all along the production system (e.g., multiple pests and their interaction with cropping practices) $[23,113]$. The cooperation between farmers and DT developers through participatory educational approaches [114] might be the best solution towards the development of DTs capable of supporting broad issues in IPM and to fine-tune DT's features to stakeholders' needs [115]. In the words of Wearin [115], 'Indeed, lack of education of IPM developers about the perceptions of farmers is probably a much greater obstacle to implementation than the reverse.' The capacity of DTs to respond to specific stakeholders' requirements is then of paramount importance towards the adoption of these tools within IPM schemes. The DTs for IPM must be able to tackle the issues of multiple stakeholders' categories (e.g., single farmers, farmer cooperatives, big farming companies, advisors, consultants, policy-makers, etc.); this requires the consideration of the appropriate spatial (from local to area-wide) and temporal (from short- to mid-term decisions) scale in relation to the type of problem and the type of stakeholder. The lack of adoption of a DT is often the result of a failure in responding and tackling real farmers' problems $[27,32]$. Therefore, involving end-users during the various developmental phases of the DTs might be a solution for solving the implementation problem and increasing the rate of adoption of DTs $[103,116,117]$. For instance, Oliver and colleagues [116] provided a protocol that included the involvement of UK farmers during the development of a DT within a participatory educational scheme.

\subsection{The DT Has Been Calibrated and Validated}

A key aspect to be considered when selecting a DT is whether the models implemented have been calibrated and validated. With calibration, we refer to the practice of estimating a model's parameters by solving the model's equations using observational data for both dependent and independent variables; the aim is to minimize the deviation between predicted and observed data. Once the calibration procedure proves satisfactory, the model must be evaluated in its capacity to provide reliable predictions of the biological processes it addresses. This procedure is called model validation and consists of comparing model outputs against field data (data must be different from those used in model calibration). Validation aims to demonstrate that the model is able to replicate real observations under different biotic and/or abiotic conditions (with respect to those used for model calibration) and guarantees the reliability of the model, as well as the possibility to generalize the model's outputs under different contexts (also called robustness of the model). For providing valuable information to final users and facilitating the selection of a DT, validation should also include a comparison of different models simulating the same process, when available [118]. The validation process is often performed by the model's developers because it requires thorough knowledge about the model including the modelling approach implemented, the equations used, and the biological processes represented. 
Calibration and validation might be time-consuming and difficult to perform, especially when the DT accounts for multiple variables. Techniques of parameters' estimation (based on stochastic approaches and Bayesian methods) might facilitate the process of DT's calibration and validation [119]. Lack of extensive validation affects model's usefulness, limits its potential use, and it is questionable from an economic and ethical standpoint. Errors might be not only related to inaccurate estimation of pest's presence and abundance, but also linked to misdiagnosis of pests. Unfortunately, models may be published and released to the market without a proper validation, essentially because there are no shared 'minimum requirements' to be satisfied in order to consider a model as correctly validated [23].

\subsection{The DT Is Open and Transparent}

When selecting a DT for its use in IPM, a careful evaluation of the model's algorithms and computer codes is important. This evaluation is sometimes difficult as computer codes are often not available for one of the following reasons: (i) The code is unknown to the end-user and not published; (ii) the code is published but only partially described; and (iii) the models are tweaked but without documentation of the improvements made. The lack of transparency relating to the computer code might cause difficulties during model calibration and validation by third persons (i.e., different from the developer) and contributes to the lack of adoption of DTs. Even though end-users are mainly interested on the accuracy and the reliability of the outputs provided, increasing the code's transparency (especially among modellers that might replicate and test the codes) might increase DT's trustfulness and thus the rate of adoption. Efforts in increasing the transparency of DT algorithms include the open-source and the knowledge-sharing approaches. The open-source approach implies that the DT and the related codes are: (i) Released and publicly available in open-source platforms and (ii) licensed under a general public license ensuring that users have the right to consult, modify, enhance, and redistribute the code. The knowledge-sharing approach implies that technical and practical knowledge on the uses of the DTs are made available and exchanged between the developers, the final users, and the other interested parties [120]. This requires that: (i) Information linked to DTs and the code is provided to the end-users; (ii) final users are kept informed about the availability of knowledge; (iii) ensure that end-users have access to knowledge; and (iv) foster the access and the use of knowledge.

\subsection{The DT Is User-Friendly}

User-friendliness means the DT is simple for people to use [22,121]. The following is a list of some of the most important requirements a DT software should satisfy to guarantee user-friendliness:

- Learning time. Clarity of the instruction manual and limitation of the time requirements for learning how to use the DT. The organization of training, seminars, workshops, and continuous support to users (e.g., through extension services and experts) may facilitate the long-term adoption of DTs;

- Time spent for navigating in the DT to obtain the information. Some DTs are time consuming because of tedious input requirements or delays in data processing. The time demand on the user has been recognized as a paramount element in determining the adoption of DTs [22,98]. The time needed for inputting, processing, and analyzing data is often a shortcoming for several DTs, discouraging their use within the IPM schemes. For example, the users of the GPFARM (https://www.ars.usda.gov/plains-area/fort-collins-co/center-for-agricultural-resourcesresearch/rangeland-resources-systems-research/docs/system/gpfarm/), a DT for strategic planning of the whole farm, declared not to have enough time to provide inordinate information requested as input by the system; moreover, the excessive run-time required discouraged adoption by producers and consultants;

- Timely information. The information should be provided in a timely manner in order to be effective within the decision-making process. For example, decisions about the control of grape downy mildew (Plasmopara viticola) are taken every $12 \mathrm{~h}$ during the most critical periods of the season, 
and thus information supporting decision-making should be delivered by a DT considering this time interval;

- Time spent for input requirements. Relevant data supplying inputs to DTs are often related to: (i) Agro-meteorology; (ii) crop production and phenology; and (iii) pest presence and abundance. DTs must be supported by monitoring activities and sensors' networks timely supplying up-to-date data that are needed to run models and generate outputs. Difficulties in rapidly updating the databases (e.g., weather data) reduce the usefulness of the system to the growers;

- Clarity of the output. This is a crucial point for the adoption of a DT [22,121]. Nowadays, most of the DTs are delivered through web-platforms or applications integrating a user-friendly graphical user interface (GUI) allowing the user to navigate within the DT, and consult the main outputs and recommendations. Therefore, accessibility to the use of DTs can be highly increased by the development of easy-to-use GUIs, which can be evaluated following structured methodologies [22,121]. Furthermore, the information provided should not be redundant, difficult to read, or irrelevant to the end-user. Regarding this, Worm and colleagues [122] investigated the direct link between the rate of acceptance of a DT and the overall design of the system. For example, presenting the outputs of a DT in quantitative terms, might lead to difficulties in the interpretation of the information. In some cases, a graphic representation, indicating for instance the overall risks linked to a consequent management action, might be more informative for the end-user [23].

\subsection{The DT Is Regularly Maintained and Updated}

DTs require regular maintenance and updating. Providing periodic software updates and related users' guides and training has a positive influence on the adoption rate of a DT [24]. As for the DTs development, also updating DTs requires a multi-actor approach that involves multiple expertise ranging from IT developers, modellers, ecologists, and agronomists. It also benefits from the direct involvement of end-users, especially for the definition of model outputs (in relation to their needs), the type of access required, and the communication means (e.g., through web-based applications, phone SMS, emails).

The development of a DT needs adequate time and financial resources. This is frequently covered by ad-hoc research projects that should include the costs for maintaining the system after the end of the project and ensuring periodic update. When maintenance and updating costs are not provided by the specific project, these costs must be provided by end-users in the form of fees. For instance, Jones and colleagues [101] estimated the value of the fee to be paid for a DT supporting IPM in tree fruit by calculating the costs needed for the maintenance of the DT (including the training activities) and the number of users.

\subsection{The DT Supports and Does Not Replace the Farmer as Decision-Maker}

An important aspect to consider when developing a DT is the definition of the role of the different actors (the DT itself, the service provider, the end-user, etc.) in the decision-making process. For example, the unsuccessful adoption of some DTs aimed at simulating human decision-making processes (e.g., expert systems) was attributed to the fact that the end-user felt left out of the decision-making process [22]. Indeed, the aim of a DT should be not to replace humans, but to provide a support to the end-users in making a rational decision based on the available information (and possibly the potential uncertainties) [22,37]. Therefore, the users should be considered as the main actors in the decision-making process, while the DT should provide relevant, suitable, and accessible information targeted to their own needs and integrated in their own decisional process [22,123]. The rate of acceptance and adoption of DTs aimed at supporting human decision making was higher when compared to DTs used as a proxy of human decision process [24]. 


\subsection{The DT Provides Benefits to Users}

Once a DT has been calibrated and validated against real data, it is important to evaluate whether its use leads to real benefits in IPM programs. According to the food and agriculture organization of the United Nations (FAO), the adoption of any DT is highly correlated to the economic advantages (real or perceived) that it might bring [22]. To this aim, it is important to carry out observations in order to prove and possibly quantify, the advantages in terms of pest control, rational use of chemicals, increased crop yield, and crop quality. For example, the DT named vite.net (https://www.horta-srl.it/sito/en/portfolio-item/vite-net/), implemented for sustainable vineyard protection, provided a saving of $195 € / \mathrm{ha} /$ year by reducing the amount of fungicides by an average of $24 \%$, when compared to the standard practice in organic farming across Italy [32]. The same DT was tested across Europe and facilitated the same quality as the standard practice with a fungicide savings of $31.5 \%$ in IPM and $43.7 \%$ in organic farming, respectively, leading to an overall decrease of the costs linked to disease management of approximately $200 € /$ ha/year [124]. Farmers seem to be more prone to adopt (and thus trust) DTs for low-to mid-income crops (i.e., extensive or semi-intensive cropping systems). For intensive crops, farmers are more prone to increase the number of treatments in order to minimize the risk of yield loss (and thus income) [24]. However, exceptions exist as in the case of previously cited viticulture [32,125].

Frequently, users are sceptical about the real contribution of DTs to better decision-making for IPM. Therefore, the establishment of the practical impact and market credentials of a DT is really important [123], and evidence of the relevance the DT can have on the activities of potential users and the resulting benefits must be carefully demonstrated. For instance, Caffi and colleagues [126,127] demonstrated that the use of DTs for the management of powdery and downy mildews in viticulture led to a reduction on the application of pesticides by $30 \%$. Considering that the costs of pesticide treatments against these diseases might reach $500 € /$ ha per year, a DT is able to decrease these costs by $150 € /$ ha per year. Unfortunately, demonstration of the real benefits generated by the DT are available only in a few cases. In these cases, a DT can gain farmers' trust if it is adopted by users that are considered as expert and trustworthy, or if it is widely used in the same or similar crop-growing area of the adopter. The introduction of a new technology (such as a DT) in the context of pest management represents a 'sustaining innovation' that needs to be supported by significant changes of approach and practices [128]. The introduction of a DT can be considered as a discontinuous technological advancement, as it requires the complete redesign of the working procedures within the farming system as, for example, a regular field monitoring or consultation of the DT. Therefore, the adoption of a DT requires, in addition to the evaluation of the potential benefits that might bring, the recognition of the influence that this tool might have on the overall organization of the farming system [128]. However, demonstration that the DT provides economic benefits does not ensure its wide adoption [116,129]. Kuhlmann [130] offered an economic explanation: A more effective reduction of agricultural costs can be reached by reducing farming inputs, investing in low-priced inputs, and reducing farm operations in respect to the adoption of a DT. However, also considering the potential benefit that a DT can bring in terms of long-term economic, social, and environmental sustainability may support its acceptability. From this viewpoint, the advantages of using a DT include also the support at: (i) Preserving the status of the agroecosystem; (ii) reducing the use of external inputs (e.g., plant protection products); (iii) enhancing crop yield and quality; (iv) meeting government and community expectations about landscape management; and (v) ensuring access to markets characterized by high standards related to environmental safety and product quality. Quantifying these not strictly economic benefits requires the adoption of multi-criteria approaches [118].

\section{Concluding Remarks}

The efficient and rational control of pests, while ensuring agricultural productivity and economic and environmental sustainability, is at the basis of the IPM approach. The successful implementation of IPM requires proper incentives to farmers [131] and that information and tools for pest monitoring 
and for supporting decision-making are made available to professional users. These tools are designed to support the end-users by providing early warnings, facilitating pest monitoring, early diagnosis, forecasts about pest dynamics, and providing sound thresholds for the application of pesticides. In the framework of implementation of IPM, it becomes of paramount importance to provide to the end-users reliable, user-friendly, accessible, and up-to-date DTs while, if needed, adapting their outputs according to specific stakeholders' needs and/or to specific local conditions. In this paper, we reviewed the main factors influencing the adoption of DTs in IPM, which are related, among others, to technical constraints, farmers' attitude towards the adoption of new technologies and tools, the capacity of the DTs to solve farmers' real problems, reliability, and user-friendliness. We also provide and discuss the critical factors that should be considered by: (i) DTs developers for providing efficient tools, and by (ii) multiple users' types for selecting the DTs to be implemented in practical IPM at various spatio-temporal scales. These factors should be considered in the frame of developing reliable DTs for pest management and able to support decisional processes within IPM schemes implemented in diverse agricultural, geographical, and socio-economic contexts. Increasing the adoption of DTs in IPM by a wider public and facilitating their use under diverse contexts requires careful investments and the capacity to create synergies among stakeholders (DTs producers, policy-makers, farmers, etc.) and different expertise (modellers, agronomists, pathologists, entomologists, etc.) within a multi-actor approach. These expertise are also important for the continuous software maintenance and the periodic updates that are essential requirements for effective use of DTs in IPM. Knowledge sharing is a key principle for ensuring DTs openness and transparency. However, this is only possible if all the stakeholders' categories involved can envisage benefits. Finally, the organization of training, seminars, workshops, and continuous support to farmers (e.g., through extension services and experts) must be provided in order to sustain the long-term adoption of DTs in IPM.

Funding: This research received no external funding.

Acknowledgments: Part of this work was developed within the SHARE4IPM proposal, submitted under the call H2020-SFS-2018-2020. Authors thanks the SHARE4IPM consortium - and particularly Josep Armengol, Nikolaos Marianos, Paolo Racca, Francesca Salinari, Serge Savary, Dimitrios Tsitsigiannis, and Ine Van der Fels-Klerxfor the contribution in developing the proposal text. This work has been partially supported by "Fondazione Cariplo" (Italy) and "Regione Lombardia" (Italy) under the project: "La salute della persona: lo sviluppo e la valorizzazione della conoscenza per la prevenzione, la diagnosi precoce e le terapie personalizzate". Grant Emblematici Maggiori 2015-1080.

Conflicts of Interest: The authors declare no conflict of interest.

\section{Appendix A}

Table A1. List of decision tools implemented in the EU.

\begin{tabular}{|c|c|c|c|}
\hline Crop & N. of Pests & N. of DTs ${ }^{1}$ & Pest/Mycotoxin Names \\
\hline Almond & 7 & 7 & $\begin{array}{c}\text { Alternaria alternata, Eurytoma amygdali, Monilinia fructicola, Myzus } \\
\text { persicae, Taphrina deformans, Tetranychus urticae, Wilsonomyces } \\
\text { carpophilus }\end{array}$ \\
\hline Apples & 5 & 9 & $\begin{array}{c}\text { Argyrotaenia pulchellana, Cydia pomonella, Erwinia amylovora, } \\
\text { Pandemis cerasana, Venturia inaequalis }\end{array}$ \\
\hline Asparagus & 1 & 1 & Stemphylium vesicarium \\
\hline Barley & 12 & 17 & $\begin{array}{c}\text { Blumeria graminis, Deoxynivalenol (DON), Drechslera teres, Fusarium } \\
\text { avenaceum, F. culmorum, F. graminearum, F. langhsetiae, F. poae, F. } \\
\text { sporotrichoides, Microdochium nivale, Puccinia hordei, Rhynchosporium } \\
\text { secalis }\end{array}$ \\
\hline Blackberries & 1 & 1 & Drosophila suzukii \\
\hline Cherries & 2 & 2 & Drosophila suzukii, Monilinia fructicola \\
\hline Cucurbits & 3 & 4 & Golovinomyces orontii, Podosphaera xanthii, Pseudoperonospora cubensis \\
\hline Eldberry & 1 & 1 & Drosophila suzukii \\
\hline Flowers (cut) & 1 & 1 & Botrytis cinerea \\
\hline
\end{tabular}


Table A1. Cont.

\begin{tabular}{|c|c|c|c|}
\hline Crop & N. of Pests & N. of DTs ${ }^{1}$ & Pest/Mycotoxin Names \\
\hline Grapes & 10 & 19 & $\begin{array}{c}\text { Aspergillus carbonarius, Botrytis cinerea, Drosophila suzukii, Erysiphe } \\
\text { necator, Guignardia bidwellii, Lobesia botrana, Ochratoxin A, Planococcus } \\
\text { ficus, Plasmopara viticola, Scaphoidues titanus }\end{array}$ \\
\hline Kiwifruit & 1 & 1 & Pseudomonas syringae pv. actinidiae \\
\hline Legumes & 10 & 10 & $\begin{array}{l}\text { Ascochyta rabiei, A. pinodes, Alternaria alternata, Bruchus rufimanus, } \\
\text { Colletotrichum lindemuthianum, C. lupini, Cydia nigrana, Helicoverpa } \\
\text { (=Heliothis) armigera, Sitona sp., Uromyces phaseoli }\end{array}$ \\
\hline Loquat & 1 & 1 & Fusicladium eriobotryae \\
\hline Maize & 16 & 19 & $\begin{array}{l}\text { Larvae and adults of Agriotes lineatus, A. obscurus, A. sordidus, A. } \\
\text { sputator, Aspegillus flavus, Chaetocnema pulicaria, Diabrotica virgifera, } \\
\text { Fusarium graminearum, F. langsethiae, F. verticillioides, Ostrinia } \\
\text { nubilalis, Peniciullium spp., Aflatoxins, Fumonisins, DON, T2/HT2 }\end{array}$ \\
\hline Oats & 1 & 1 & DON \\
\hline Oilseed rape & 5 & 5 & $\begin{array}{c}\text { Brassicogethes aeneus, Ceutorhynchus napi, C. pallidactylus, Psylliodes } \\
\text { chrysocephalus, Sclerotinia sclerotiorum }\end{array}$ \\
\hline Olives & 2 & 6 & Fusicladium oleaginum, Bactrocera oleae \\
\hline Onions & 1 & 2 & Peronospora desctructor \\
\hline Peaches & 9 & 13 & $\begin{array}{c}\text { Adoxophyes orana, Anarsia lineatella, Cydia molesta, Monilinia fructicola, } \\
\text { Monilinia spp., Sphaerotheca pannosa, Taphrina deformans, } \\
\text { Wilsonomyces carpophilus, Xanthomonas arboricola }\end{array}$ \\
\hline Pears & 6 & 8 & $\begin{array}{l}\text { Argyrotaenia pulchellana, Cydia pomonella, Erwinia amylovora, } \\
\text { Pandemis cerasana, Stemphylium vesicarium, Venturia pirina }\end{array}$ \\
\hline Pistachio & 1 & 1 & Septoria spp. \\
\hline Plums & 2 & 2 & Cydia funebrana, Drosophila suzukii \\
\hline Potatoes & 9 & 18 & $\begin{array}{c}\text { Larvae and adults of Agriotes lineatus, A. obscurus, A. sordidus, A. } \\
\text { sputator, Alternaria alternata, A. solani, Leptinotarsa decemlineata, } \\
\text { Phthorimaea operculella, Phytophthora infestans }\end{array}$ \\
\hline Raspberries & 1 & 1 & Drosophila suzukii \\
\hline Rice & 5 & 5 & $\begin{array}{l}\text { Cochliobolus miyabeanus, Pyricularia oryzae, Rhizoctonia solani, Rice } \\
\text { Tungro S and B viruses, Xanthomonas campestris pv. oryzae }\end{array}$ \\
\hline Rye & 3 & 3 & Puccinia recondita, Blumeria graminis, Rhynchosporium secalis \\
\hline Strawberry & 1 & 2 & Botrytis cinerea \\
\hline Sugar beet & 2 & 8 & Erysipahe betae, Cercospora beticola \\
\hline Tobacco & 1 & 1 & Peronospora tabacina \\
\hline Tomatoes & 7 & 11 & $\begin{array}{c}\text { Alternaria solani, Helicoverpa (=Heliothis) armigera, Oidium lycopersici, } \\
\text { Phthorimaea operculella, Phytopthora infestans, Pseudomonas syringae, } \\
\text { Xanthomonas campestris pv. vesicatoria }\end{array}$ \\
\hline Triticale & 6 & 6 & $\begin{array}{c}\text { Puccinia triticina, P. striiformis, Blumeria graminis, Rhynchosporium } \\
\text { secalis, Parastagonospora nodorum, Zymoseptoria tritici }\end{array}$ \\
\hline Wheat & 22 & 31 & $\begin{array}{c}\text { Blumeria graminis, BYDV, Fusarium avenaceum, F. culmorum, } F \text {. } \\
\text { graminearum, F. langhsetiae, F. poae, F. sporotrichoides, Microdochium } \\
\text { nivale, Parastagonospora nodorum, Puccinia recondita, P. striiformis, } P \text {. } \\
\text { triticina, Pyrenophora tritici-repentis, Rhopalosiphum maidis, R. padi, } \\
\text { Sitobion avenae, Zymoseptoria tritici, DON, Nivalenol (NIV), T2-HT2, } \\
\text { Zearalenon (ZEA) }\end{array}$ \\
\hline TOTAL & 155 & 217 & \\
\hline
\end{tabular}

\section{References}

1. IPPC; ISPM; FAO. International Plant Protection Convention/International Standards for Phytosanitary Measures/Glossary of Phytosanitary Terms; Food and Agriculture Organization: Rome, Italy, 2007.

2. Ehler, L.E. Integrated pest management (IPM): Definition, historical development and implementation, and the other IPM. Pest Manag. Sci. 2006, 62, 787-789. [CrossRef] [PubMed]

3. Barzman, M.; Bàrberi, P.; Birch, A.N.E.; Boonekamp, P.; Dachbrodt-Saaydeh, S.; Graf, B.; Hommel, B.; Jensen, J.E.; Kiss, J.; Kudsk, P.; et al. Eight principles of integrated pest management. Agron. Sustain. Dev. 2015, 35, 1199-1215. [CrossRef]

4. Kilgore, W.W.; Doutt, R.L. Pest Control. Biological, Physical, and Selected Chemical Methods; Academic Press: New York, NY, USA, 1967.

5. Nagothu, U.S.; Ketelaar, J.W. Save and Grow; Food and Agriculture Organization: Rome, Italy, 2018; Volume 6, ISBN 9789251068717. 
6. Kogan, M.; Bajwa, W.I. Integrated pest management: A global reality? An. Soc. Entomol. Bras. 2006, 28, 1-25. [CrossRef]

7. Rajalathi, R.; Lagnaoui, A.; Schillhorn-Van Veen, T.; Pehu, E. Sustainable Pest Management: Achievements and Challenges; Agriculture and Rural Development Report No. 32714-GLB; The World Bank: Washington, DC, USA, 2005.

8. Gliessman, S.R.; Engles, E. Agroecology: The Ecology of Sustainable Food Systems; CRC Press: Boca Raton, FL, USA, 2014; ISBN 9781439895610.

9. Norris, R.F.; Caswell-Chen, E.P.; Kogan, M. Concepts in Integrated Pest Management; Prentice Hall: Upper Saddle River, NJ, USA, 2003; ISBN 0130870161.

10. Nutter, F.W.; Teng, P.S.; Royer, M.H. Terms and Concepts for Yield, Crop Loss, and Disease Thresholds. Plant Dis. 1993, 77, 211-215.

11. Gadanakis, Y.; Bennett, R.; Park, J.; Areal, F.J. Evaluating the Sustainable Intensification of arable farms. J. Environ. Manag. 2015, 150, 288-298. [CrossRef]

12. Pretty, J.N. The sustainable intensification of agriculture. Nat. Resour. Forum 1997, 21, 247-256. [CrossRef]

13. Trumble, J.T. IPM: Overcoming Conflicts in Adoption. Integr. Pest Manag. Rev. 1998, 3, 195-207. [CrossRef]

14. Deike, S.; Pallutt, B.; Christen, O. Investigations on the energy efficiency of organic and integrated farming with specific emphasis on pesticide use intensity. Eur. J. Agron. 2008, 28, 461-470. [CrossRef]

15. Angioni, A.; Dedola, F. Three years monitoring survey of pesticide residues in Sardinia wines following integrated pest management strategies. Environ. Monit. Assess. 2013, 185, 4281-4289. [CrossRef]

16. Lechenet, M.; Bretagnolle, V.; Bockstaller, C.; Boissinot, F.; Petit, M.-S.; Petit, S.; Munier-Jolain, N.M. Reconciling Pesticide Reduction with Economic and Environmental Sustainability in Arable Farming. PLoS ONE 2014, 9, e97922. [CrossRef] [PubMed]

17. Bommarco, R.; Kleijn, D.; Potts, S.G. Ecological intensification: Harnessing ecosystem services for food security. Trends Ecol. Evol. 2013, 28, 230-238. [CrossRef] [PubMed]

18. Jeger, M. Bottlenecks in IPM. Crop Prot. 2000, 19, 787-792. [CrossRef]

19. Zalucki, M.P.; Adamson, D.; Furlong, M.J. The future of IPM: Whither or wither?: Overview. Aust. J. Entomol. 2009, 48, 85-96. [CrossRef]

20. Parsa, S.; Morse, S.; Bonifacio, A.; Chancellor, T.C.B.; Condori, B.; Crespo-Pérez, V.; Hobbs, S.L.A.; Kroschel, J.; Ba, M.N.; Rebaudo, F.; et al. Obstacles to integrated pest management adoption in developing countries. Proc. Natl. Acad. Sci. USA 2014, 111, 3889-3894. [CrossRef] [PubMed]

21. Pardo, G.; Riravololona, M.; Munier-Jolain, N.M. Using a farming system model to evaluate cropping system prototypes: Are labour constraints and economic performances hampering the adoption of Integrated Weed Management? Eur. J. Agron. 2010, 33, 24-32. [CrossRef]

22. McCown, R. Changing systems for supporting farmers' decisions: Problems, paradigms, and prospects. Agric. Syst. 2002, 74, 179-220. [CrossRef]

23. Magarey, R.D.; Travis, J.W.; Russo, J.M.; Seem, R.C.; Magarey, P.A. Decision Support Systems: Quenching the Thirst. Plant Dis. 2002, 86, 4-14. [CrossRef]

24. Shtienberg, D. Will Decision-Support Systems Be Widely Used for the Management of Plant Diseases? Annu. Rev. Phytopathol. 2013, 51, 1-16. [CrossRef]

25. Gent, D.H.; De Wolf, E.; Pethybridge, S.J. Perceptions of Risk, Risk Aversion, and Barriers to Adoption of Decision Support Systems and Integrated Pest Management: An Introduction. Phytopathology 2010, 101, 640-643. [CrossRef]

26. Goble, T. Integrated Pest Management: Concepts, Tactics, Strategies and Case Studies; Radcliffe, E., Hutchison, W., Cancelado, R., Eds.; Cambridge University Press: Cambridge, UK, 2009.

27. Rossi, V.; Caffi, T.; Salinari, F. Helping farmers face the increasing complexity of decision-making for crop protection. Phytopathol. Mediterr. 2012, 51, 457-479.

28. Trematerra, P. Aspects related to decision support tools and Integrated Pest Management in food chains. Food Control 2013, 34, 733-742. [CrossRef]

29. Narayana Reddy, M.; Rao, N.H. GIS-Based Decision Support Systems in Agriculture; National Academy of Agricultural Research Management: Rajendranagar, India, 1995.

30. Akhavan, P.; Jafari, M.; Fathian, M. Critical success factors of knowledge management systems: A multi-case analysis. Eur. Bus. Rev. 2006, 18, 97-113. [CrossRef] 
31. Keating, B.; McCown, R. Advances in farming systems analysis and intervention. Agric. Syst. 2001, 70, 555-579. [CrossRef]

32. Rossi, V.; Salinari, F.; Poni, S.; Caffi, T.; Bettati, T. Addressing the implementation problem in agricultural decision support systems: The example of vite.net ${ }^{\circledR}$. Comput. Electron. Agric. 2014, 100, 88-99. [CrossRef]

33. Meijer, B.J.M.; Kamp, J.A.L.M. Development and introduction of farm management systems. In Proceedings of the Workshop on Computer-Based Plant Protection and Advisory Systems, Copenhagen, Denmark, 27-29 November 1991; Secher, B.J.M., Murali, N.S., Eds.; Springer: Berlin, Germany, 1991.

34. Rabbinge, R.; Rijsdijk, F.H. EPIPRE: A Disease and Pest Management System for Winter Wheat, taking Account of Micrometeorological Factors 1. EPPO Bull. 1983, 13, 297-305. [CrossRef]

35. Zadoks, J.C. A quarter century of disease warning, 1958-1983. Plant Dis. 1984, 68, 352-355. [CrossRef]

36. Damos, P.; Karabatakis, S. Real time pest modeling through the World Wide Web: Decision making from theory to praxis. IOBC WPRS Bull. 2013, 91, 253-258.

37. Hochman, Z.; Carberry, P.S. Emerging consensus on desirable characteristics of tools to support farmers' management of climate risk in Australia. Agric. Syst. 2011, 104, 441-450. [CrossRef]

38. Rossi, V.; Meriggi, P.; Caffi, T.; Giosué, S.; Bettati, T. A web-based decision support system for managing durum wheat crops. In Decision Support Systems, Advances in; BoD-Books on Demand: Norderstedt, Germany, 2010.

39. Leffelaar, P. On Systems Analysis and Simulation of Ecological Processes with Examples in CSMP and FORTRAN; Springer: Dordrecht, The Netherlands, 2012.

40. Wainwright, J.; Mulligan, M. Environmental Modelling; Wiley-Blackwell: Chichester, UK, 2002.

41. Madden, L.V.; Ellis, M.A. How to Develop Plant Disease Forecasters. In Experimental Techniques in Plant Disease Epidemiology; Springer: Berlin/Heidelberg, Germany, 1988; pp. 191-208.

42. Shoemaker, C. Applications of dynamic programming and other optimization methods in pest management. IEEE Trans. Automat. Contr. 1981, 26, 1125-1132. [CrossRef]

43. Mahaman, B.; Passam, H.; Sideridis, A.; Yialouris, C. DIARES-IPM: A diagnostic advisory rule-based expert system for integrated pest management in Solanaceous crop systems. Agric. Syst. 2003, 76, 1119-1135. [CrossRef]

44. Schepers, H. Decision support systems for integrated control of late blight. Plant Breed. Seed Sci. 2004, 50, 57-61.

45. Damos, P. Modular structure of web-based decision support systems for integrated pest management. A review. Agron. Sustain. Dev. 2015, 35, 1347-1372. [CrossRef]

46. Caffi, T.; Legler, S.E.; Bugiani, R.; Rossi, V. Combining sanitation and disease modelling for control of grapevine powdery mildew. Eur. J. Plant Pathol. 2013, 135, 817-829. [CrossRef]

47. Dury, J.; Schaller, N.; Garcia, F.; Reynaud, A.; Bergez, J.E. Models to support cropping plan and crop rotation decisions. A review. Agron. Sustain. Dev. 2012, 32, 567-580. [CrossRef]

48. Reichenbach, S.E.; Waltman, W.J.; Jindal, G.; Nelson, L.A.; Meyer, S.J.; Peake, J.S.; Fithian, W.; Dappen, P. The Planting Date Calculator: A Decision-Support Tool for Agriculture; Computer Science and Engineering Department, University of Nebraska-Lincoln: Lincoln, NE, USA, 2003.

49. Carisse, O.; Tremblay, D.-M.; Jobin, T.; Walker, A.S. Disease Decision Support Systems: Their Impact on Disease Management and Durability of Fungicide Effectiveness. In Fungicides; InTech: London, UK, 2010.

50. Haverkort, A.J.; Struik, P.C. (Eds.) Potato in Progress: Science Meets Practice; Wageningen Academic Publishers: Wageningen, The Netherlands, 2005.

51. Haneklaus, S.; Schroeder, D.; Schnug, E. Decision Making Strategies for Fertilizer Use in Precision Agriculture. In Precision Agriculture; Robert, P.C., Rust, R.H., Larson, W.E., Eds.; American Society of Agronomy, Crop Science Society of America, Soil Science Society of America: Madison, WI, USA, 1999.

52. He, J.; Wang, J.; He, D.; Dong, J.; Wang, Y. The design and implementation of an integrated optimal fertilization decision support system. Math. Comput. Model. 2011, 54, 1167-1174. [CrossRef]

53. MacCarthy, D.S.; Kihara, J.; Masikati, P.; Adiku, S.G.K. Decision support tools for site-specific fertilizer recommendations and agricultural planning in selected countries in sub-Sahara Africa. Nutr. Cycl. Agroecosyst. 2018, 110, 343-359. [CrossRef]

54. Machet, J.-M.; Dubrulle, P.; Damay, N.; Duval, R.; Julien, J.-L.; Recous, S. A Dynamic Decision-Making Tool for Calculating the Optimal Rates of N Application for 40 Annual Crops While Minimising the Residual Level of Mineral N at Harvest. Agronomy 2017, 7, 73. [CrossRef] 
55. Kleinhenz, B.; Rossberg, D. Structure and development of decision-support systems and their use by the state plant protection services in Germany. EPPO Bull. 2000, 30, 93-97. [CrossRef]

56. Racca, P.; Kleinhenz, B.; Zeuner, T.; Keil, B.; Tschöpe, B.; Jung, J. Decision Support Systems in Agriculture: Administration of Meteorological Data, Use of Geographic Information Systems (GIS) and Validation Methods in Crop Protection Warning Service. In Efficient Decision Support Systems_Practice and Challenges From Current to Future; InTech: London, UK, 2011.

57. Jensen, A.L.; Boll, P.S.; Thysen, I.; Pathak, B. Pl@nteInfo ${ }^{\circledR} \_$A web-based system for personalised decision support in crop management. Comput. Electron. Agric. 2000, 25, 271-293. [CrossRef]

58. Thysen, I. PlanteInfo-Ten years of online information and decision support for crop production in Denmark. In Proceedings of the Making Science Work on the Farm: A Workshop on Decision Support Systems for Irish Agriculture; Joint Working Group in Applied Agricultural Meteorology (AGMET), Dublin, Ireland, 25 January 2007; pp. 11-23.

59. VanKirk, J.R.; Isard, S.A.; Cardwell, K.F.; Draper, M.A. The ipmPIPE: Overview, Lessons, Opportunities, and Challenges. J. Integr. Pest Manag. 2012, 3, 1-7. [CrossRef]

60. Gilioli, G.; Pasquali, S.; Marchesini, E. A modelling framework for pest population dynamics and management: An application to the grape berry moth. Ecol. Modell. 2016, 320, 348-357. [CrossRef]

61. Damos, P.; Savopoulou-Soultani, M. Temperature-driven models for insect development and vital thermal requirements. Psyche 2012, 2012, 123405. [CrossRef]

62. Gilioli, G.; Pasquali, S.; Marchesini, E.; Salinari, F. Simulation models-Insect pests. In Proceedings of the MoDeM_IVM Conference at Vinitech, Bordeaux, France, 29 November 2012.

63. Cicogna, A.; Dietrich, S.; Gani, M.; Giovanardi, R.; Sandra, M. Use of meteorological radar to estimate leaf wetness as data input for application of territorial epidemiological model (downy mildew-Plasmopara viticola). Phys. Chem. Earth Parts A/B/C 2005, 30, 201-207. [CrossRef]

64. Rossi, V.; Caffi, T.; Giosuè, S.; Bugiani, R. A mechanistic model simulating primary infections of downy mildew in grapevine. Ecol. Modell. 2008, 212, 480-491. [CrossRef]

65. Caffi, T.; Rossi, V.; Legler, S.E.; Bugiani, R. A mechanistic model simulating ascosporic infections by Erysiphe necator, the powdery mildew fungus of grapevine. Plant Pathol. 2011, 60, 522-531. [CrossRef]

66. Rossi, V.; Onesti, G.; Legler, S.E.; Caffi, T. Use of systems analysis to develop plant disease models based on literature data: Grape black-rot as a case-study. Eur. J. Plant Pathol. 2015, 141, 427-444. [CrossRef]

67. González-Domínguez, E.; Caffi, T.; Ciliberti, N.; Rossi, V. A Mechanistic Model of Botrytis cinerea on Grapevines That Includes Weather, Vine Growth Stage, and the Main Infection Pathways. PLoS ONE 2015, 10, e0140444. [CrossRef]

68. Plant, R.E.; Mangel, M. Modeling and Simulation in Agricultural Pest Management. SIAM Rev. 1987, 29, 235-261. [CrossRef]

69. Higley, L.; Pedigo, L. Economic Thresholds for Integrated Pest Management; University of Nebraska Press: Lincoln, NE, USA, 1996.

70. Brown, G.C. Simple Models of Natural Enemy Action and Economic Thresholds. Am. Entomol. 1997, 43, 117-124. [CrossRef]

71. Garrett, K.A.; Forbes, G.A.; Savary, S.; Skelsey, P.; Sparks, A.H.; Valdivia, C.; Van Bruggen, A.H.C.; Willocquet, L.; Djurle, A.; Duveiller, E.; et al. Complexity in climate-change impacts: An analytical framework for effects mediated by plant disease. Plant Pathol. 2011, 60, 15-30. [CrossRef]

72. Perini, A.; Susi, A. Developing a decision support system for integrated production in agriculture. Environ. Model. Softw. 2004, 19, 821-829. [CrossRef]

73. Aggarwal, P.K.; Kalra, N.; Chander, S.; Pathak, H. InfoCrop: A dynamic simulation model for the assessment of crop yields, losses due to pests, and environmental impact of agro-ecosystems in tropical environments. I. Model description. Agric. Syst. 2006, 89, 1-25. [CrossRef]

74. Food and Agriculture Organization of the United Nations. A Modelling System for the Assessment of the Agricultural Impacts of Climate Change; FAO: Rome, Italy, 2015; p. 28.

75. Cerda, R.; Avelino, J.; Gary, C.; Tixier, P.; Lechevallier, E.; Allinne, C. Primary and Secondary Yield Losses Caused by Pests and Diseases: Assessment and Modeling in Coffee. PLoS ONE 2017, 12, e0169133. [CrossRef] [PubMed] 
76. Savary, S.; Nelson, A.D.; Djurle, A.; Esker, P.D.; Sparks, A.; Amorim, L.; Bergamin Filho, A.; Caffi, T.; Castilla, N.; Garrett, K.; et al. Concepts, approaches, and avenues for modelling crop health and crop losses. Eur. J. Agron. 2018, 100, 4-18. [CrossRef]

77. Prasad, Y.; Prabhakar, M. Pest monitoring and forecasting. Integrated Pest Management: Principles and Practice; Cabi: Oxfordshire, UK, 2012; pp. 41-57.

78. Ravlin, F.W. Development of monitoring and decision-support systems for integrated pest management of forest defoliators in North America. For. Ecol. Manage. 1991, 39, 3-13. [CrossRef]

79. Birch, L.C. The Role of Weather in Determining the Distribution and Abundance of Animals. Cold Spring Harb. Symp. Quant. Biol. 1957, 22, 203-218. [CrossRef]

80. Gage, S.H.; Whalon, M.E.; Miller, D.J. Pest Event Scheduling System for Biological Monitoring and Pest Management. Environ. Entomol. 1982, 11, 1127-1133. [CrossRef]

81. Otuka, A.; Watanabe, T.; Suzuki, Y.; Matsumura, M.; Furuno, A.; Chino, M. Real-time prediction system for migration of rice planthoppers Sogatella furcifera (Horvath) and Nilaparvata lugens (Stal) (Homoptera: Delphacidae). Appl. Entomol. Zool. 2005, 40, 221-229. [CrossRef]

82. Nurhayati, E.; Koesmaryono, Y. Impron Predictive Modeling of Rice Yellow Stem Borer Population Dynamics under Climate Change Scenarios in Indramayu. IOP Conf. Ser. Earth Environ. Sci. 2017, 58, 012054. [CrossRef]

83. Cook, S.M.; Döring, T.F.; Ferguson, A.W.; Martin, J.L.; Skellern, M.P.; Smart, L.E.; Watts, N.P.; Welham, S.J.; Woodcock, C.; Pickett, J.A. Development of an Integrated Pest Management Strategy for Control of Pollen Beetles in Winter Oilseed Rape; HGCA Project Report No. 504; Home Grown Cereals Authority (HGCA): Kenilworth, UK, 2013; pp. 2-32.

84. Rossi, V.; Racca, P.; Battilani, P.A. simulation model for Cercospora leaf spot epidemics on sugarbeet. Phytopathol. Mediterr. 1994, 33, 105-112.

85. Caffi, T.; Rossi, V. Fungicide models are key components of multiple modelling approaches for decision-making in crop protection. Phytopathol. Mediterr. 2018, 57, 153-169.

86. Bouma, E. GEWIS, a weather-based decision support system for timing the application of plant protection products. EPPO Bull. 2003, 33, 483-487. [CrossRef]

87. Gil, E. Design of a Decision Support Method to Determine Volume Rate for Vineyard Spraying. Appl. Eng. Agric. 2009, 25, 145-151. [CrossRef]

88. Barani, A.; Franchi, A.; Bugiani, R.; Montermini, A. Efficacy of unit canopy row spraying system for control of European vine moth (Lobesia botrana) in vineyards. Agric. Eng. Int. 2008, 10, 08005.

89. Gil, E.; Llorens, J.; Landers, A.; Llop, J.; Giralt, L. Field validation of dosaviña, a decision support system to determine the optimal volume rate for pesticide application in vineyards. Eur. J. Agron. 2011, 35, 33-46. [CrossRef]

90. Vacante, V.; Gilioli, G. The effects of triflumuron against the western flower thrips (Frankliniella occidentalis (Pergande)) on pepper: An evaluation based on the analysis of population dynamics. J. Appl. Entomol. 2003, 127, 413-420. [CrossRef]

91. Cohen, J.E.; Schoenly, K.; Heong, K.L.; Justo, H.; Arida, G.; Barrion, A.T.; Litsinger, J.A. A Food Web Approach to Evaluating the Effect of Insecticide Spraying on Insect Pest Population Dynamics in a Philippine Irrigated Rice Ecosystem. J. Appl. Ecol. 1994, 31, 747. [CrossRef]

92. Barclay, H.J. Models for Pest Control Using Predator Release, Habitat Management and Pesticide Release in Combination. J. Appl. Ecol. 1982, 19, 337. [CrossRef]

93. Tsai, M.; Elgethun, K.; Ramaprasad, J.; Yost, M.; Felsot, A.; Hebert, V.; Fenske, R. The Washington aerial spray drift study: Modeling pesticide spray drift deposition from an aerial application. Atmos. Environ. 2005, 39, 6194-6203. [CrossRef]

94. Jarvis, N.J.; Hollis, J.M.; Nicholls, P.H.; Mayr, T.; Evans, S.P. MACRO—DB: A decision-support tool for assessing pesticide fate and mobility in soils. Environ. Model. Softw. 1997, 12, 251-265. [CrossRef]

95. Rydahl, P.; Hagelskjaer, L.; Pedersen, L.; Bojer, O.Q. User interfaces and system architecture of a web-based decision support system for integrated pest management in cereals. EPPO Bull. 2003, 33, 473-481. [CrossRef]

96. Brown, C.D.; Hart, A.; Lewis, K.A.; Dubus, I.G. p-EMA (I): Simulating the environmental fate of pesticides for a farm-level risk assessment system. Agronomie 2003, 23, 67-74. [CrossRef]

97. Strassemeyer, J.; Daehmlow, D.; Dominic, A.R.; Lorenz, S.; Golla, B. SYNOPS-WEB, an online tool for environmental risk assessment to evaluate pesticide strategies on field level. Crop Prot. 2017, 97, $28-44$. [CrossRef] 
98. Knight, J.D. The role of decision support systems in integrated crop protection. Agric. Ecosyst. Environ. 1997, 64, 157-163. [CrossRef]

99. Yang, X.B. Risk Assessment: Concepts, Development, and Future Opportunities. Plant Heal. Prog. 2003, 4, 16. [CrossRef]

100. Webster, J.P.G. Reflections on the economics of decision support systems. In Proceedings of the 3rd international Congress for Computer Technology. Integrated Decision Support Systems in Agriculture-Successful Practical Applications, Frankfurt, Germany, 27-30 May 1990; Deutsche Landwirtschafts-Gesellschaft (DLG): Frankfurt, Germany, 1990; pp. 307-317.

101. Jones, V.P.; Brunner, J.F.; Grove, G.G.; Petit, B.; Tangren, G.V.; Jones, W.E. A web-based decision support system to enhance IPM programs in Washington tree fruit. Pest Manag. Sci. 2010, 66, 587-595. [CrossRef]

102. Matthews, K.B.; Schwarz, G.; Buchan, K.; Rivington, M.; Miller, D. Wither agricultural DSS? Comput. Electron. Agric. 2008, 61, 149-159. [CrossRef]

103. McCown, R.L. A cognitive systems framework to inform delivery of analytic support for farmers' intuitive management under seasonal climatic variability. Agric. Syst. 2012, 105, 7-20. [CrossRef]

104. Kerr, D. Factors influencing the Development and Adoption of Knowledge Based Decision Support Systems for Small, Owner-Operated Rural Business. Artif. Intell. Rev. 2004, 22, 127-147. [CrossRef]

105. Ascough, J.C.; Mcmaster, G.S.; Dunn, G.H.; Andales, A.A. The GPFARM DS for agroecosystem sustainability: The past, future, and lessons learned. In Proceedings of the Environmental Modeling International Conference Proceedings. International Modeling and Environmental Software Society, Modeling for Environment's Sake, Ottawa, ON, Canada, 5-8 July 2010; pp. 2540-2547.

106. Kuehne, G.; Llewellyn, R.; Pannell, D.J.; Wilkinson, R.; Dolling, P.; Ouzman, J.; Ewing, M. Predicting farmer uptake of new agricultural practices: A tool for research, extension and policy. Agric. Syst. 2017, 156, 115-125. [CrossRef]

107. Rose, D.C.; Sutherland, W.J.; Parker, C.; Lobley, M.; Winter, M.; Morris, C.; Twining, S.; Ffoulkes, C.; Amano, T.; Dicks, L.V. Decision support tools for agriculture: Towards effective design and delivery. Agric. Syst. 2016, 149, 165-174. [CrossRef]

108. Rogers, E.M. Diffusion of Innovations; Simon and Schuster: New York, NY, USA, 2010.

109. Jørgensen, L.N.; Noe, E.; Nielsen, G.C.; Jensen, J.E.; Ørum, J.E.; Pinnschmidt, H.O. Problems with disseminating information on disease control in wheat and barley to farmers. Eur. J. Plant Pathol. 2008, 121, 303-312. [CrossRef]

110. Thomas, C.S.; Skinner, P.W.; Fox, A.D.; Greer, C.A.; Gubler, W.D. Utilization of GIS/GPS-Based Information Technology in Commercial Crop Decision Making in California, Washington, Oregon, Idaho, and Arizona. J. Nematol. 2002, 34, 200-206. [PubMed]

111. Gubler, W.D.; Rademacher, M.R.; Vasquez, S.J. Control of Powdery Mildew Using the UC Davis Powdery Mildew Risk Index; APS: St. Paul, MN, USA, 1999.

112. Lybbert, T.J.; Gubler, W.D. California Wine Grape Growers' Use of Powdery Mildew Forecasts. ARE Updat. 2008, 11, 11-14.

113. Rossi, V.; Salinari, F.; Bernazzani, R.; Giosuè, S.; Mazzoni, E. Models for pest's epidemiology: Review, documentation and evaluation for Pest Risk Analysis (Mopest). EFSA Support. Publ. 2009, 6, 28E. [CrossRef]

114. Röling, N.; Wagemakers, M.A.E. Facilitating Sustainable Agriculture: Participatory Learning and Adaptive Management in Times of Environmental Uncertainty; Cambridge University Press: Cambridge, UK, 2000.

115. Wearing, C.H. Evaluating the IPM Implementation Process. Annu. Rev. Entomol. 1988, 33, 17-38. [CrossRef]

116. Oliver, D.M.; Fish, R.D.; Winter, M.; Hodgson, C.J.; Heathwaite, A.L.; Chadwick, D.R. Valuing local knowledge as a source of expert data: Farmer engagement and the design of decision support systems. Environ. Model. Softw. 2012, 36, 76-85. [CrossRef]

117. Igbaria, M.; Guimaraes, T. Empirically testing the outcomes of user involvement in DSS development. Omega 1994, 22, 157-172. [CrossRef]

118. Caffi, T.; Helsen, H.H.M.; Rossi, V.; Holb, I.J.; Strassemeyer, J.; Buurma, J.S.; Capowiez, Y.; Simon, S.; Alaphilippe, A. Multicriteria evaluation of innovative IPM systems in pome fruit in Europe. Crop Prot. 2017, 97, 101-108. [CrossRef]

119. Gilioli, G.; Pasquali, S.; Ruggeri, F. Bayesian Inference for Functional Response in a Stochastic Predator-Prey System. Bull. Math. Biol. 2008, 70, 358-381. [CrossRef] [PubMed] 
120. Öhlmér, B.; Olson, K.; Brehmer, B. Understanding farmers' decision making processes and improving managerial assistance. Agric. Econ. 1998, 18, 273-290. [CrossRef]

121. Cox, P.G. Some issues in the design of agricultural decision support systems. Agric. Syst. 1996, 52, 355-381. [CrossRef]

122. Worm, G.I.M.; van der Helm, A.W.C.; Lapikas, T.; van Schagen, K.M.; Rietveld, L.C. Integration of models, data management, interfaces and training support in a drinking water treatment plant simulator. Environ. Model. Softw. 2010, 25, 677-683. [CrossRef]

123. Stone, P.; Hochman, Z. If Interactive Decision Support Systems Are the Answer, Have We Been Asking the Right Questions; New Direct Reprint no: 5084; The Regional Institute Ltd: Canberra, Australia, 2004.

124. Pertot, I.; Caffi, T.; Rossi, V.; Mugnai, L.; Hoffmann, C.; Grando, M.S.; Gary, C.; Lafond, D.; Duso, C.; Thiery, D.; et al. A critical review of plant protection tools for reducing pesticide use on grapevine and new perspectives for the implementation of IPM in viticulture. Crop Prot. 2017, 97, 70-84. [CrossRef]

125. Rossi, V.; Caffi, T.; Legler, S.E.; Carotenuto, E.; Bigot, G. Large-scale application of a web-based Decision Support System for sustainable viticulture. In Proceedings of the IOBC/WPRS Working Group "Integrated protection and production in Viticulture", Ascona, Switzerland, 13-17 October 2013.

126. Caffi, T.; Rossi, V.; Bugiani, R. Evaluation of a Warning System for Controlling Primary Infections of Grapevine Downy Mildew. Plant Dis. 2010, 94, 709-716. [CrossRef]

127. Caffi, T.; Legler, S.E.; Rossi, V.; Bugiani, R. Evaluation of a Warning System for Early-Season Control of Grapevine Powdery Mildew. Plant Dis. 2012, 96, 104-110. [CrossRef]

128. McCown, R.L.; Carberry, P.S.; Hochman, Z.; Dalgliesh, N.P.; Foale, M.A. Re-inventing model-based decision support with Australian dryland farmers. 1. Changing intervention concepts during 17 years of action research. Crop Pasture Sci. 2009, 60, 1017. [CrossRef]

129. Rickert, U. Role and potential of IT, Intranet and Internet for advisory services. In Proceedings of the European Conference of European Federation for Information Technology in Agriculture, Bonn, Germany, 27-30 September 1999; Helbig, R., Schiefer, G., Eds.; FAO: Rome, Italy, 1999.

130. Kuhlmann, F. Farm-level-information-systems: Developments and perspectives. In Proceedings of the 2nd European Conference of the European Federation for Information Technology in Agriculture, Food, and the Environment, Bonn, Germany, 27-30 September 1999; pp. 7-17.

131. Lefebvre, M.; Langrell, S.R.H.; Gomez-y-Paloma, S. Incentives and policies for integrated pest management in Europe: A review. Agron. Sustain. Dev. 2015, 35, 27-45. [CrossRef] 